\title{
Adaption of Lung Fibroblasts to Fluoro-Edenite Fibers: Evaluation of Molecular and Physiological Dynamics
}

\author{
Adriana C. E. Graziano ${ }^{a}$ Caterina Ledda ${ }^{b}$ Carla Loreto ${ }^{c}$ Venera Cardile ${ }^{a}$ \\ aDepartment of Biomedical and Biotechnological Science - Section of Physiology, University of Catania, \\ Catania, Italy, ${ }^{b}$ Department of Clinical and Experimental Medicine - Section of Occupational Medicine, \\ University of Catania, Catania, Italy, 'Department of Biomedical and Biotechnological Science - Section \\ of Anatomy, Histology and Movement Sciences, University of Catania, Catania, Italy
}

\section{Key Words}

Asbestos-like fiber • Lung fibroblasts • Extracellular matrix • Senescence $\bullet$ In vitro experiment

\begin{abstract}
Background/Aims: The fluoro-edenite fibrous amphibole was identified as an environmental pollutant associate to risk of carcinogenicity. In Sicily (Italy), it represents a public health issue because fluoro-edenite fibers are present in the soil of Biancavilla, a town located on the southwest slopes of the volcano Etna. Since the relationship between exposure to fluoro-edenite and the onset of lung disorders have been documented, in vitro studies were performed to clarify the mechanisms of damage, but most aspects remain unknown. Here, we focus on the effects of mineral fibers in a primary culture of lung fibroblasts. We supposed that the cells react to fluoro-edenite exposure by establishing a process of adaption that could modify their metabolic activity, their proliferation, and their physiological functions, as the production of extracellular matrix (ECM) components. Methods: To verify our hypothesis, we used immunofluorescence, cell proliferation, senescence, apoptosis, scratch, Western blot, Reverse transcription-polymerase chain reaction (RT-PCR), and evaluation of extracellular matrix components assays. Results: Results demonstrated that lung fibroblasts react to fluoro-edenite by a down-regulation of mitochondrial activity, a reduction of cell growth and migration, and a resistance to apoptosis. These elements suggested the induction of a premature senescent phenotype that was confirmed by senescence-associated beta-galactosidase (SA- $\beta$-Gal) activity, and by the analysis of ECM elements. We found an unbalance of collagens ratio, and changes in matrix metalloproteinase 3 production and release. Conclusion: Our data suggest that fluoro-edenite-induced senescence of lung fibroblasts could be an early and underestimated step that may drive fibroblasts toward a fibrotic and carcinogenic phenotype.
\end{abstract}




\section{Cellular Physiology Cell Physiol Biochem 2021;55:327-343

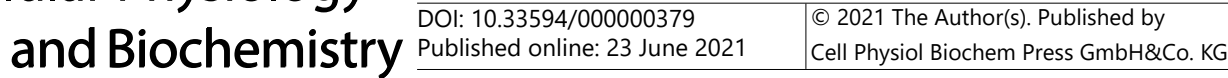 \\ Graziano et al.: Fluoro-Edenite on Human Fibroblasts}

\section{Introduction}

In Sicily (Italy), an environmental pollutant was identified in the fluoro-edenite fibrous amphibole present in the soil of Biancavilla [1,2], a town located on the south-west slopes of the volcano Etna. According to the reports produced by the Italian Istituto Superiore di Sanità [3-7], the International Agency for Research on Cancer (IARC) assigned a carcinogenicity risk to fluoro-edenite exposure in the frame of Monograph 111 [8], identifying a new public health issue. Although the relationship between the exposure to fluoro-edenite present in the area of Biancavilla and the onset of mesothelioma and other lung disorders - such as plural plaques and fibrosis - have been well documented [9-14], the sequence of molecular events remains to be clarified.

Several in vitro models have been applied to create the mechanisms of fluoro-edeniteinduced damage. On lung alveolar epithelial A549 cell line, it has been reported that the exposure to fluoro-edenite reduces the cell proliferation rate and increases the release of pro-inflammatory cytokine $[15,16]$, probably by activation of phosphoinositide-specific phospholipase C [15, 17], and overexpression of retinoblastoma protein [18]. A comparison between A549 and MeT-5A cells was made by Pugnaloni et al. [19], underscoring changes in cytoplasmic F-actin networks, cell motility, VEGF and beta-catenin expression according to cell sensitivity. Moreover, the assessment of inflammatory condition was reported in monocytemacrophage cell line J774 [19, 20] and in mesothelial Met-5A [21]. The inflammatory condition seems to be also associated to oxidative damage because fluoro-edenite induced the production of reactive oxygen species (ROS) accompanied to DNA damage, alteration of cell metabolism and increase in the release of lactic dehydrogenase [22]. More recently, fluoro-edenite-exposed primary cultures of human lung fibroblasts were found to express higher level of fibulin-3 protein than the unexposed ones [23], reacting similarly to MeT5A [24]. Globally, all these in vitro data revealed that fluoro-edenite affects both airways and lung parenchyma cells, establishing processes of inflammation and carcinogenesis. An interesting aspect resides on the different reactivity toward fluoro-edenite: it has been reported that primary cultures of human lung fibroblasts react to fibers in a less intense manner than cell lines A549 and J774 [22]. This event should be partially justified by activation of defense and protection mechanisms [25], or by the hypothesis that primary culture activates physiological process that could be not well evaluated in immortalized cell lines.

Here, we analyzed the interaction of fluoro-edenite with primary culture of lung fibroblasts in order to enlighten mechanisms that could affect the cellular functions. Fibroblasts are cells of mesenchymal origin that are greatly distributed in numerous tissues. Within the lung interstitium, the most usually recognized cells are resident fibroblasts and pulmonary fibroblasts has been also described in the connective tissue of the airway wall under the surface epithelium [26]. Generally, they act to maintain the homeostasis of extracellular matrix (ECM) and serve as effector cells during injury repair, playing an active role in lung health and disease. According to this background, we supposed that the fibroblasts could react to fluoro-edenite exposure by establishing, at first, a process of physiological adaption that should modify their metabolic activity, proliferation, and physiological functions, as the production of ECM components. These events could turn into cell reaction with the instauration of a phenotype that may drive and support a profibrotic and oncogenic microenvironment.

\section{Materials and Methods}

\section{Human fibroblasts cultures and treatments}

The normal, non-immortalized, human adult lung fibroblasts applied in this study were a kind gift of Prof. Carlo Vancheri (Department of Clinical and Experimental Medicine, University of Catania, Italy). Cells were routinely cultured in RPMI 1640 medium supplemented by fetal bovine serum (10\%), penicillin (100 U/ml), and streptomycin $(100 \mu \mathrm{g} / \mathrm{ml})$ (Thermo Fisher Scientific, Milan, Italy), and maintained at 


\section{Cellular Physiology Cell Physiol Biochem 2021;55:327-343 \\ \begin{tabular}{c|c|c|c|}
\hline DOl: 10.33594/000000379 & 02021 The Author(s). Published by \\
\hline
\end{tabular} \\ Published online: 23 June 2021 Cell Physiol Biochem Press GmbH\&Co. KG \\ Graziano et al.: Fluoro-Edenite on Human Fibroblasts}

$37^{\circ} \mathrm{C}$, in an incubator with controlled relative humidity (95\%) and $\mathrm{CO}_{2}(5 \%)$. Every three days, the medium was changed, and every 10-12 days subcultures were performed. In the experimental sets, cells at a passage earlier than the tenth were used. Fluoro-edenite fibers from Biancavilla were sterilized under UV irradiation for ten minutes, suspended in culture medium, sonicated and tested on experimental cultures at concentrations of 10,50 , and $100 \mu \mathrm{g} / \mathrm{ml}\left(1.06,10.6\right.$, and $\left.21.2 \mu \mathrm{g} / \mathrm{cm}^{2}\right)$ for 48 or 72 hours.

Characterization and validation of primary lung fibroblasts by immunocytochemistry

For immunofluorescence assays, the routinely protocol of our lab $[27,28]$ was applied. The following primary antibodies were applied overnight: rabbit monoclonal anti-vimentin (ab92547, Abcam Inc. Cambridge, MA, USA), mouse monoclonal anti-CD31 (PECAM-1 89C2, \#3528, Cell Signaling, UK), mouse monoclonal anti-desmin (sc-65983, Santa Cruz Biotechnology, DBA, Milan, Italy), rabbit polyclonal antiP4HB (ab85564, Abcam Inc. Cambridge, MA, USA). After three wash in PBS for 5 min to remove unbounded antibodies, the appropriate fluorescent dye-conjugated secondary antibody was incubated for 1 hour: the Cy3-conjugated goat anti-rabbit and the fluorescein isothiocyanate-conjugated goat anti-mouse secondary antibody (AP187C and AP181F, both from Millipore, Milan, Italy). The 4',6-diamidino-2-phenylindole (DAPI) was applied to perform DNA staining. Negative controls involving the omission of the primary antibody were included. Image acquisition and analysis were performed with Leica Application Suite software on a Leica fluorescence microscope.

\section{MTT assay}

The metabolic activity of human adult lung fibroblasts was assessed by 3-[4,5-dimethylthiazol-2yl]-2,5 diphenyl tetrazolium bromide (MTT) assay [29]. Human adult lung fibroblasts (density of 10000 cells/well in a 96-well plate) were treated as previously described and incubated for 3 hours with MTT solution (stock at $5 \mathrm{mg} / \mathrm{ml}$ in PBS diluted 1:10 in culture medium). The formazan produced by mitochondrial dehydrogenase was solubilized in DMSO $(100 \mu \mathrm{l} /$ well $)$ and the absorbance values read at $\lambda=550 \mathrm{~nm}$ in a microplate reader (Titertek Multiskan, DAS, Italy). Data were reported as percentage of formazan production \pm SEM with respect to untreated cells.

Cellular senescence assay

Cellular senescence was investigated by the 96-Well Cellular Senescence Assay Kit (Cell Biolabs, San Diego, USA) following the manufacturer's instructions. Human adult lung fibroblasts were plated and treated as previously described. After incubation, total proteins were extracted in lysis buffer and quantified by Pierce's bicinchoninic acid (BCA) protein assay (Thermo Fisher Scientific, Milan, Italy). Meantime, lysates were incubated with SA- $\beta$-Gal substrate for 3 hours at $37^{\circ} \mathrm{C}$. The fluorescence was quantified using Victor 3 multilabel counter (Perkin Elmer, Milan, Italy) at excitation/emission wavelengths of $\lambda=360 / 465 \mathrm{~nm}$. Data were normalized to protein content, and the SA- $\beta$-Gal activity of the normalized samples was expressed as relative fluorescent units (R.F.U.) \pm SEM.

\section{Detection of the active form of caspase-3}

To detect active caspase-3, the PathScan® Sandwich ELISA (Cell Signaling \#7190; EuroClone, Milan, Italy) was used according to producer's instruction. After treatment, cells were lysated and equal amounts of protein were added in top of microwells. After 2-hours incubation at $37^{\circ} \mathrm{C}$, the wells were washed 4 times with the wash buffer, and 1-hour incubation with the reconstituted detection antibody was performed at $37^{\circ} \mathrm{C}$. After an additional wash was made to eliminate unbounded antibody, and the HRP-linked secondary antibody was added into each well and incubated for $30 \mathrm{~min}$ at $37^{\circ} \mathrm{C}$. Then, a 10 -minutes incubation was done at $37^{\circ} \mathrm{C}$ in presence of tetramethylbenzidine (TMB) substrate. The absorbance was read at $\lambda=450$ $\mathrm{nm}$ in a microplate reader (Titertek Multiskan, DAS, Italy) within 30 minutes after the addition of the stop solution that blocked the reaction. Value was reported as average of color intensity of three independent experiments performed in triplicate.

In vitro scratch assay

The in vitro scratch assay was performed as reported [30,31], with minor modification. Specifically, we used Thermo Scientific ${ }^{\mathrm{TM}} \mathrm{Nunc}^{\mathrm{TM}}$ cell-culture treated 24-well plates in which cells shown a maximum adhesion (Thermo Fisher Scientific, Milan, Italy). Briefly, cells were treated with $4 \mathrm{mg}$ of mitomycin C (Sigma 


\section{Cellular Physiology Cell Physiol Biochem 2021;55:327-343 \\ \begin{tabular}{ll|l} 
and Biochemisty $10.33594 / 000000379$ & C) 2021 The Author(s). Published by \\
Published online: 23 June 2021 & Cell Physiol Biochem Press GmbH\&Co. KG
\end{tabular} \\ Graziano et al.: Fluoro-Edenite on Human Fibroblasts}

Aldrich, Milan, Italy), to abolish proliferation, seeded and allowed to achieve confluence overnight. The resulting monolayer was scratched using a 0.2-ml plastic pipette tip and, after PBS washing, culture medium with or without fluoro-edenite was added. Cells were monitored every 12 hours up to 72 hours.

\section{Crystal violet staining}

Crystal violet staining was performed according to Chen et al. [32] on scratched cells. Briefly, cells were fixed in paraformaldeide (4\% in PBS) and stained with crystal violet $(0.01 \%)$ for 20 min at room temperature. The excess of dye was eliminated by three washing procedures with PBS. Cells were snapped on a microscope (Zeiss Axioplan, Carl Zeiss, Milan, Italy) equipped with a camera (Axicam, Zeiss, Carl Zeiss, Milan, Italy).

\section{Western blot analysis}

Western blot analysis was performed as already reported [33, 34], with some modifications. Experimental cells were plated into 6-well plates at a density of 500000 cells/well and, after the exposure to fluoro-edenite, triplicate samples were scraped, pelleted, and washed with PBS. The M-PER Mammalian Protein Extraction Reagent (Pierce, Thermo Fisher Scientific, Milan, Italy) in presence of Protease Inhibitor Cocktail (cOmplete ${ }^{\mathrm{TM}}$, Roche, Sigma-Aldrich, Milan, Italy) was applied to obtain the protein pool that was quantified by BCA protein assay (Thermo Fisher Scientific, Milan, Italy). Then, equal amounts of proteins were separated by $4-12 \%$ bolt gel electrophoresis, and transferred into transfer stacks of nitrocellulose by iBlot Gel Transfer Device (all from Thermo Fisher Scientific, Milan, Italy). The membranes were stained with Ponceau S solution to verify transfer efficiency. The immunodetection steps were automated by iBind Flex Western System device (Thermo Fisher Scientific, Milan, Italy), according to manufacturer's instruction. The following antibodies were applied: rabbit polyclonal anti-caspase-3, active (C8487, Sigma-Aldrich, 1:500), mouse monoclonal anti-Col1A1 (sc:59772, Santa Cruz Biotechnology, 1:200), mouse monoclonal anti-Col3A1 (sc-514601, Santa Cruz Biotechnology, 1:200), mouse monoclonal anti-MMP-1 (sc-21731, Santa Cruz Biotechnology, 1:200), mouse monoclonal anti-MMP-3 (sc-21732, Santa Cruz Biotechnology, 1:200), mouse monoclonal anti- $\alpha$-Tubulin (T9026, Sigma-Aldrich, 1:5000). The secondary HRP-conjugated antibodies were goat anti-rabbit and goat anti-mouse from Santa Cruz Biotechnology, Milan, Italy (sc-2030, goat anti-rabbit, 1:5000; sc-2005, goat anti mouse, 1:1000). The detection was performed using enhanced chemiluminescent solution (LiteUP, EuroClone, Milan, Italy) and Uvitec Alliance LD9 imaging system (Uvitec, Cambridge, United Kingdom). Relative quantifications were made by ImageJ software (Rasband, W.S., ImageJ, U.S. NIH), and reported as fold change of treated sample respect to unexposed cells (control), corrected by band volume of loaded control. Experiments were performed in triplicate and results expressed as fold change \pm SEM $v s$ untreated samples.

\section{Reverse transcription-polymerase chain reaction (RT-PCR)}

Cells were plated as already described for Western blot, and, after exposure to fluoro-edenite, mRNA isolation was performed by Qiazol Reagent (Qiagen, Milan, Italy), according to manufacturer' instruction. The QuantiTect Reverse Transcription Kit (Qiagen, Milan, Italy) was applied to synthesize cDNAs, after removal of genomic DNA. The cDNAs were quantified by a BioPhotometer (Eppendorf, Milan, Italy) and $100 \mathrm{ng}$ were added to each reaction mix containing 1× Rotor-Gene SYBR Green PCR Master Mix (Qiagen, Milan, Italy), $1 \mu \mathrm{M}$ of each primer (forward and reverse) and RNase-free water to a final reaction volume of $25 \mu \mathrm{l}$ [35]. Primers were from Integrated DNA Technologies (IDT, Tema Ricerca, Castenaso, Italy) and they are listed in Table 1. PCR run with the program: initial activation step $95^{\circ} \mathrm{C} 10 \mathrm{~min}$, denaturation $95^{\circ} \mathrm{C} 10 \mathrm{~s}$, annealing $60^{\circ} \mathrm{C} 30 \mathrm{~s}$, extension $72^{\circ} \mathrm{C} 30 \mathrm{~s}$ (40 cycles), final extension $72^{\circ} \mathrm{C} 10 \mathrm{~min}$, followed by melting curve analysis to confirm PCR specificity. Quantification of the housekeeping gene GAPDH as an internal control was performed for each sample. All data were normalized to GAPDH mRNA level as an endogenous control, and the absolute mRNA expression levels were calculated by the formula $2^{-\Delta C t}$. Moreover, the formula $2^{-\Delta \Delta C t}$ was applied to evaluate the relative expression of target genes in cells exposed to fluoro-edenite as external stimulus with respect to the untreated ones.

Table 1. Primers list

\begin{tabular}{lcc}
\hline Primer & Forward sequences $\left(5^{\prime}-3^{\prime}\right)$ & Reverse sequences $\left(5^{\prime}-3^{\prime}\right)$ \\
\hline COL1A1 & CCGGCTCCTGCTCCTCTTAGCG & CGTTCTGTACGCAGGTGATTGGTGG \\
COL3A1 & GGAGCTGGCTACTTCTCGC & GGGAACATCCTCCTTCAACAG \\
GAPDH & ATGACATCAAGAAGGTGGTG & CATACCAGGAAATGAGCTTG \\
MMP1 & ATGTGGCTCAGTTTGTCCTC & GCTTTCTCAATGGCATGGTC \\
MMP3 & GACAAAGGATACAACAGGGAC & TGAGTGAGTGATAGAGTGGG \\
MMP13 & TTGAGGATACAGGCAAGACT & TGGAAGTATTACCCCAAATG \\
VERSICAN 1 & CCCAGTGTGGAGGTGGTCTAC & CGCTCAAATCACTCATTCGACGTT \\
\hline
\end{tabular}




\section{Cellular Physiology Cell Physiol Biochem 2021;55:327-343

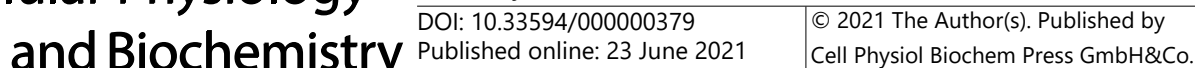 \\ Graziano et al.: Fluoro-Edenite on Human Fibroblasts}

Detection of versican levels

Versican levels in culture supernatant were measured by Human Versican ELISA Kit (Cusabio, DBA, Milan, Italy). Briefly, standards and samples were pipetted into the wells of a microplate precoated with specific anti-versican antibody for 3 hours. After washing to remove all unbound substances, a biotin conjugated antibody specific for versican was added to each well for 1 hour, followed by washing steps and incubation with avidin conjugated HRP. After the elimination of any boundless avidin-enzyme reagent by wash, the versican bounded in the initial step was developed by a substrate solution that produced a color which intensity was proportional to the amount of immobilized versican. The stop reaction was added, and the absorbance was measured at $\lambda=450 \mathrm{~nm}$ and $\lambda=540 \mathrm{~nm}$ as wavelength correction in a microplate reader (Titertek Multiskan, DAS, Italy) within no more than 5 minutes.

\section{Recognition of MMP-1 and MMP-3 release}

A double-sandwiched ELISA kit (Oncogene Research Products, San Diego, CA, USA) following manufacturer's protocol realized detection of MMP1 or MMP3. The absorbance at the end of reaction was read at $\lambda=450 \mathrm{~nm}$ by an automatic plate reader with a reference wavelength of $\lambda=570 \mathrm{~nm}$.

\section{Statistical analysis}

Experiments were repeated independently at least three times - or more when indicated - and the mean \pm SEM was calculated. One-way or two-ways variance analysis (ANOVA) were used. All statistical analyses were done by GraphPad Prism 9. A value of $p<0.05$ was considered statistically significant.

\section{Results}

\section{Characterization of human fibroblasts}

To identify our primary cultures as fibroblasts, cells were immunoassayed with different markers, as shown in Fig. 1. Cells were positive immuno-marked for the cytosolic localized structural protein vimentin, while they were negative for the muscle marker desmin (Fig. 1A). Moreover, no signal for the endothelial cell surface CD31 marker and no detectable level of prolyl-4-hydroxylase (P4HB) was found (Fig. 1B).

\section{Modulation of mitochondrial activity}

The influence of fluoro-edenite on metabolic activity of fibroblasts was evaluated by MTT assay after 48 and 72 hours of incubation with the selected pollutant at three concentrations $(10,50$ or $100 \mu \mathrm{g} / \mathrm{ml})$. Data analysis suggested that the functions of mitochondrial dehydrogenase enzymes are reduced significantly in a time-dependent manner. In fact, at 48 hours of exposure a little and not significant decrease of formazan production was

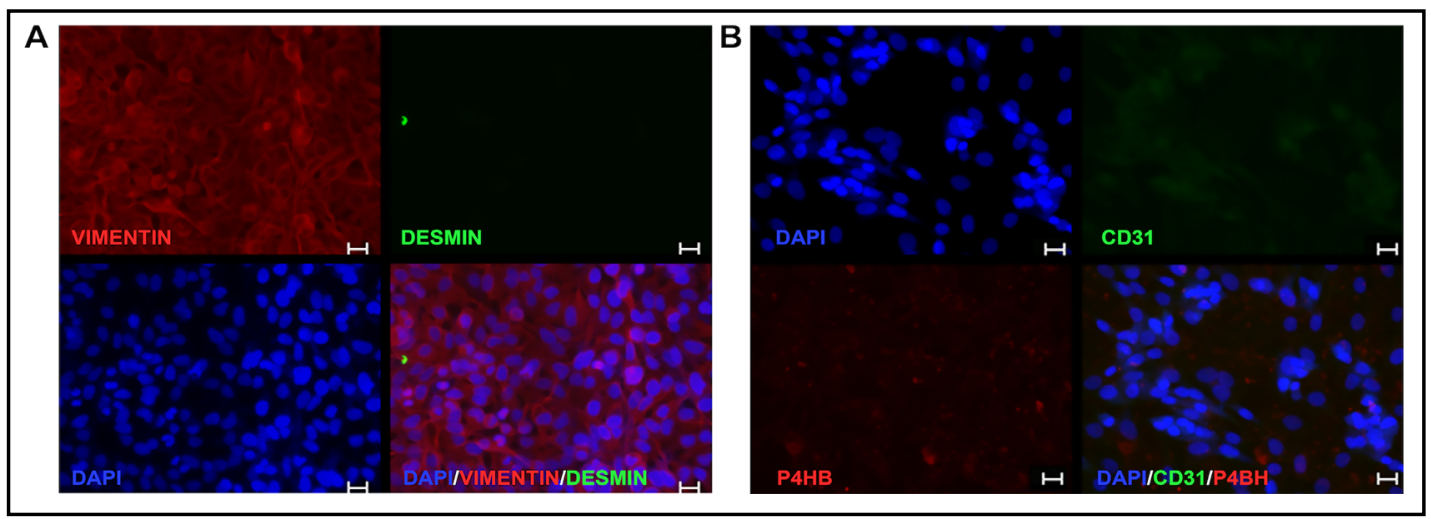

Fig. 1. Phenotypic characterization of human fibroblasts primary culture. (A) Cell immunostaining for the structural protein vimentin (red) and the muscle marker desmin (green). (B) Immunocytochemistry of prolyl-4-hydroxylase (P4HB, red), and endothelial cell surface CD31 (green). Scale bar: $20 \mu \mathrm{m}$. 
reported in presence of the highest concentration tested, while the other treatments did not interfere with mitochondrial activity (Fig. 2A). At 72 hours, indeed, the incubation with 50 and $100 \mu \mathrm{g} / \mathrm{ml}$ of fibers halved formazan production (Fig. 2B), reporting a significant statistical difference with respect to control cells $(\mathrm{p}=0.0048$ for $0 \mathrm{vs} .50 \mu \mathrm{g} /$ $\mathrm{ml} ; \mathrm{p}=0.0023$ for 0 vs. $100 \mu \mathrm{g} /$ $\mathrm{ml})$.

\section{Determination of caspase-3}

In order to detect if MTT data at 72 hours indicated induction of programmed cell death, we screened for the detection of cleaved and active form of caspase-3. As shown in Fig. 3, no detectable level of active-caspase 3 was found in our experimental conditions by Western blot (Fig. 3A) and ELISA (Fig. 3B), even if both the assays ran as demonstrated by the positive control (fibroblasts treated with staurosporine).

\section{Determination of senescence}

We analyzed the senescence of primary fibroblasts at different in vitro passages $(5,7,9,11$ and 13$)$ with and without fiber exposure. Results indicated that following in vitro division the fibroblasts senescence increased at basal level in control condition, but the incubation with fluoro-edenite reported a stronger induction. This latter was extremely marked in cells at earlier passages with respect to control and maintained constant levels in lung fibroblasts exposed to 50 and $100 \mu \mathrm{g} /$ $\mathrm{ml}$ of fibers up to passage 11 (Fig. 4A). Therefore, all the experimental sets were conducted by using cells at a passage
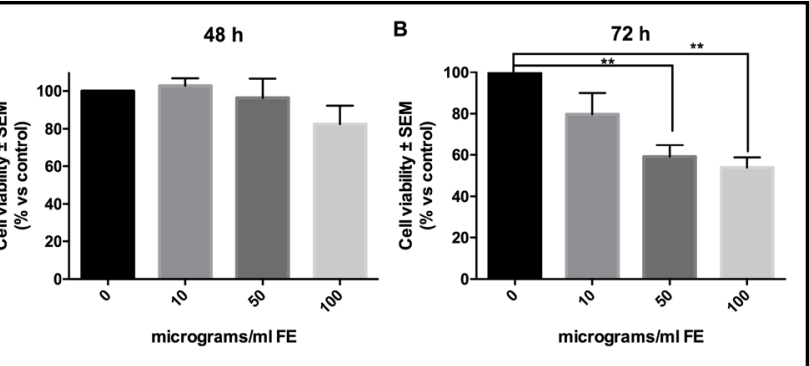

Fig. 2. Modulation of mitochondrial activity by fluoro-edenite (FE) in human fibroblasts. Conversion of MTT salt to formazan in fibroblasts exposed to 10,50 or $100 \mu \mathrm{g} / \mathrm{ml}$ of fluoro-edenite (FE) for 48 (A) and 72 (B) hours. Data are reported as percentage of ormazan production \pm SEM with respect to untreated cells. Staistical analysis by ordinary one-way ANOVA followed by Dunnett's multiple comparisons test ( $\mathrm{n}=3,{ }^{* *} \mathrm{p}<0.005$ vs untreated).

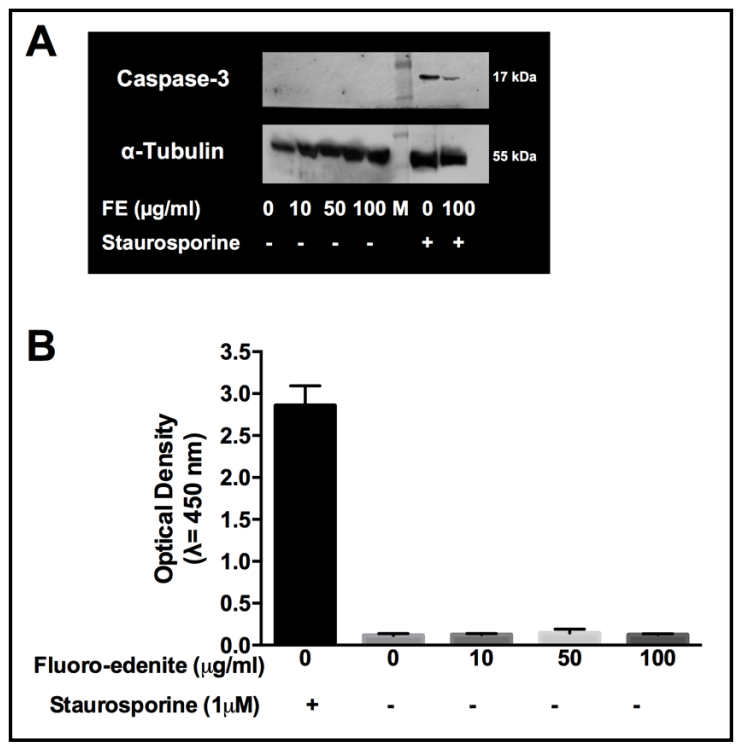

Fig. 3. Determination of caspase- 3 in human fibroblasts treated with fluoro-edenite (FE). Detection of active caspase- 3 in fibroblasts exposed to staurosporine as positive control or to $10,50,100 \mu \mathrm{g} / \mathrm{ml}$ of fluoro-edenite (FE) for 72 hours. (A) Representative immublot of caspase- 3 active form. (B) Absorbance value obtained from ELISA assay. Data are reported as mean of Relative Fluorescence Unit (R.F.U.) \pm SEM with respect to untreated cells $(n=3)$. earlier than the tenth. We coupled the in vitro scratch assay with the crystal violet staining. Results demonstrated that after 72 hours from scratch, the migration velocity of fibroblasts exposed to increasing concentrations of fluoro-edenite was reduced respect to the experimental control, turning in a defect of scratch repair (Fig. 4B). This event seemed to be linked with down-regulation of cell growth in presence of 10 and $50 \mu \mathrm{g} / \mathrm{ml}$ of fibers. When exposed to $100 \mu \mathrm{g} / \mathrm{ml}$ of fibers, lung fibroblasts clearly reported a decrease of population associated with the loss of cell-cell interactions, and a change in the shape. 
Fig. 4. Alteration of human fibroblasts senescence and migration by fluoro-edenite (FE). (A) Senescence-associated $\beta$-galactosidase (SA$\beta$-Gal) activity, normalized to total protein content, was expressed as relative fluorescent units (R.F.U.) \pm SEM ( $n=3)$. (B) Representative pictures of coupled in vitro scratch assay with the crystal violet staining. Scal bar: $100 \mu \mathrm{m}$.

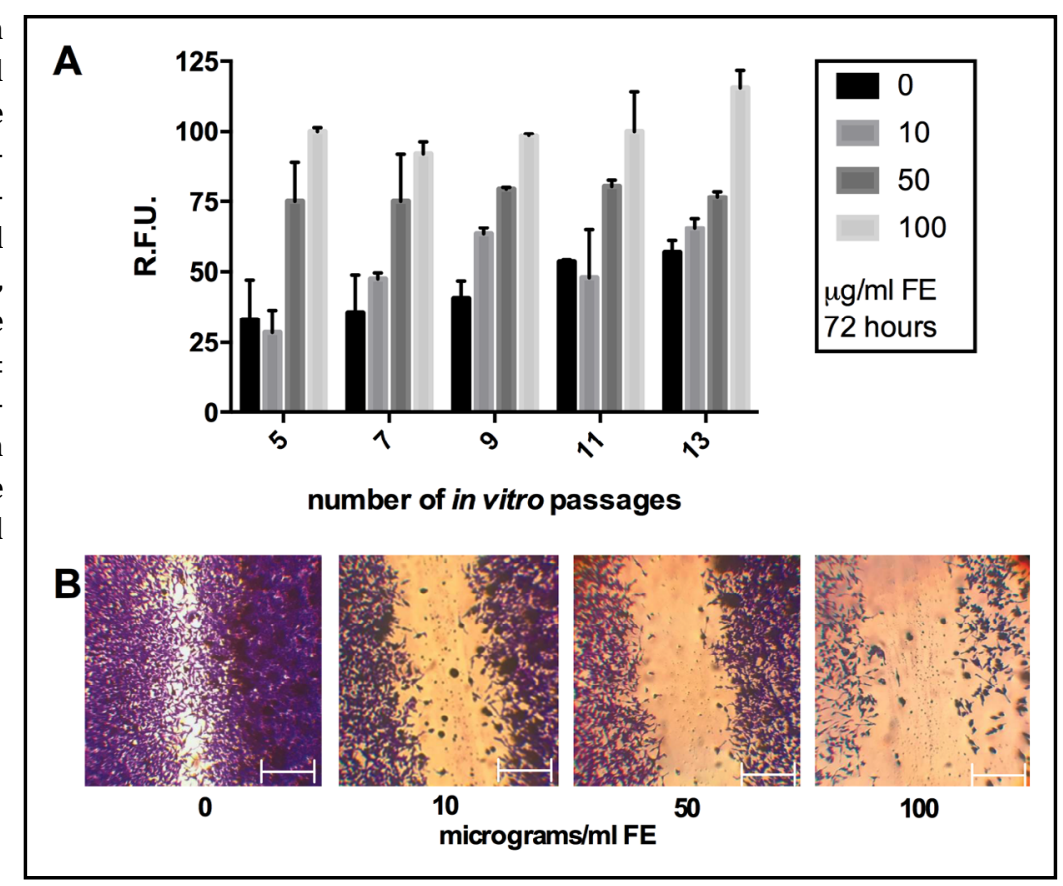

\section{Production of ECM}

According to previous observations and considering that the quality of ECM composition is involved in cell-cell interactions, shape, growth, proliferation, migration and signaling, we analyzed versican, collagen type I alpha 1 (Col1A1) and collagen type III alpha 1 (Col3A1). To perform these tests, fibroblasts at the eighth in vitro passage were maintained 4 days in culture and after exposed to fluoro-edenite for 72 hours. This protocol was applied according to our preliminary results (data not shown) in which stable levels of versican, Col1A1, and Col3A1 mRNA were detected in control condition after 5 days in culture with stable increase up to 10 days. Moreover, cells were collected by scraping because the detachment by trypsin altered Col3A1 content (data not shown). As absolute versican mRNA levels (normalized to housekeeping gene by $2^{-\Delta \Delta C t}$ method), it became higher during exposure to pollutant. Following a dose-dependent response, versican mRNA in the fluoro-edenite-treated groups progressively increased but did not reach significance until the treatment with the highest concentration of fiber $(p<0.01$; Fig. $5 A$ ). Similarly, versican levels in the supernatant of primary pulmonary fibroblasts were induced after 72 hours of treatment compared to the basal level ( $p=0.0256$; Fig. 5B). The mRNA levels of Col1A1 and Col3A1 were also modulated by fluoro-edenite. Globally, a decrease of relative mRNA levels normalized to untreated condition by $2^{-\Delta \Delta \mathrm{Ct}}$ method were associated to fibroblasts exposure at $100 \mu \mathrm{g} / \mathrm{ml}$ of fluoroedenite (Table 2). The analysis of protein levels revealed that $100 \mu \mathrm{g} / \mathrm{ml}$ of fluoro-edenite were linked to doubled quantity of Col1A1 (Fig. 6A1 and A2) and halved amount of Col3A1 (Fig. 6B1 and B2). Moreover, a significant increase of Col3A1 was detected in fibroblasts exposed to $10 \mu \mathrm{g} / \mathrm{ml}$ of fluoro-edenite. Bands analyses revealed that the ratio of Col1A1 and Col3A1 was constant at the basal conditions ranged between 1:1- 2:1 up to $50 \mu \mathrm{g} / \mathrm{ml}$ of fluoro-edenite, but it shifted to a mean value of $4: 1$ in cells exposed to $100 \mu \mathrm{g} / \mathrm{ml}$ of fluoroedenite for 72 hours, indicating an unbalance of collagens content. These findings strongly suggested the investigation on MMPs profile. 
Fig. 5. Versican mRNA and release by lung fibroblasts exposed or not to fluoro-edenite (FE) for 72 hours. (A) The mRNA expression level of versican was normalized to the housekeeping gene GAPDH by the $2-\Delta \mathrm{Ct}$ formula. Plots show median, lower quartile and upper quartile values and ranges. One-way analysis of variance followed by Bonferroni post hoc test was performed to determine whether differences between groups were statistically significant $(\mathrm{n}=4 ; \mathrm{p}<0.01)$. (B) Versican levels were determined in supernatants collected 72 hours after fiber exposure, and columns represent mean $\pm \operatorname{SEM}(n=4)$. For statistical significance one-way ANOVA followed by Dunnett's multiple comparisons test was performed to underscore difference with respect to basal condition $(\mathrm{p}<0.05)$.

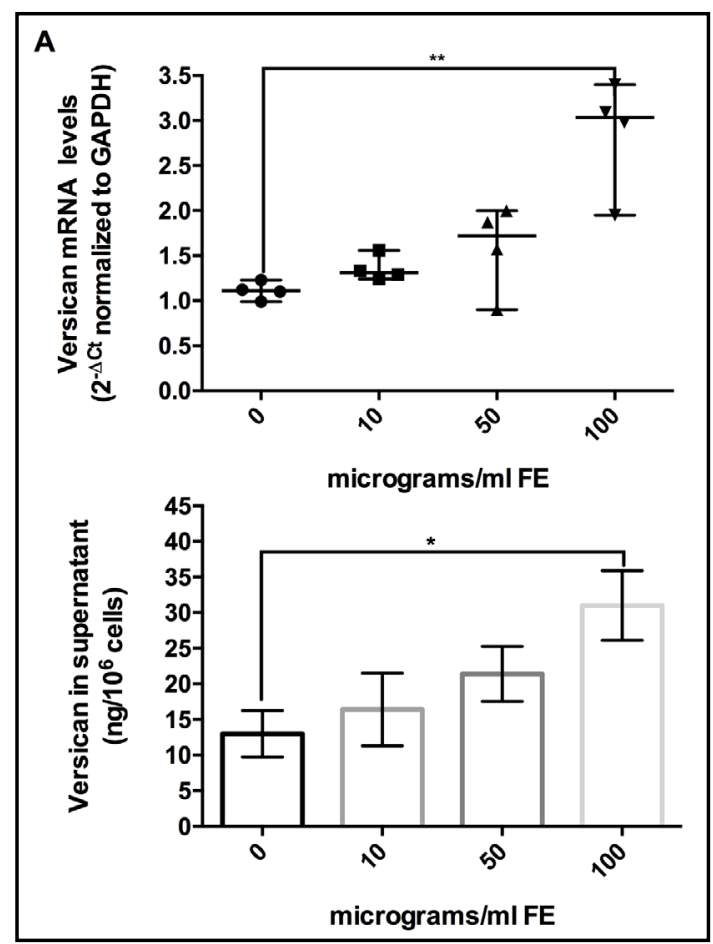

Expression of MMP1 and MMP3

To explore the influence of fluoro-edenite on the modulation of collagens, we applied the same experimental procedures and the mRNA expression and the protein level of some MMPs were analyzed. The collagenase MMP13 was not detected in all experimental setting (data not shown). Indeed, as shown in Table 3, the absolute basal mRNA levels of MMP1 and MMP3 were upregulated in pulmonary fibroblasts after incubation with 10 and $50 \mu \mathrm{g} /$ $\mathrm{ml}$ of fluoro-edenite. In presence of $100 \mu \mathrm{g} / \mathrm{ml}$ of fluoro-edenite, MMP1 mRNA decreased up to 0.3 -fold, while MMP3 mRNA increased 10-fold with respect to untreated cells (Table 3). In Fig. 7, it is shown that the fluoro-edenite treatment leads to modulation of MMPs protein expression and release. As about MMP1, no significant difference of expression (Fig. 7A1) and release (Fig. 7A2) after fluoro-edenite treatment was found with respect to control cells. Indeed, MMP3 was significantly higher expressed (Fig. 7B1) and released (Fig. 7B2) after exposure of pulmonary fibroblasts to $100 \mu \mathrm{g} / \mathrm{ml}$ of fluoro-edenite.

Considering that MMP3 protein levels were increased after 72-hours of incubation with fluoro-edenite, we next tried to elucidate whether the increased MMP3 was involved in the senescence of pulmonary fibroblasts and in the unbalanced ratio of Col1A1:Coll3A1. The MMP3-specific inhibitor UK 356618 was added to pulmonary fibroblasts medium during the incubation with fluoro-edenite, and then collagens levels and cell senescence were detected. As about collagens, the MMP3 inhibitor induced both Col1A1 and Col3A1 in control cells. In presence of fluoro-edenite, no difference was found for Col1A1 (Fig. 8A), while an increase of Col3A1 was noted after MMP3 inhibition (Fig. 8A). Bands examination revealed a reduction of the unbalanced collagens ratio in cells exposed to $100 \mu \mathrm{g} / \mathrm{ml}$ of fluoro-edenite for 72 hours, restoring it in the range of 1:1 up to 2:1. Moreover, the incubation with MMP3 inhibitor reduced significantly the senescence associated to fluoro-edenite (Fig. 8B). 


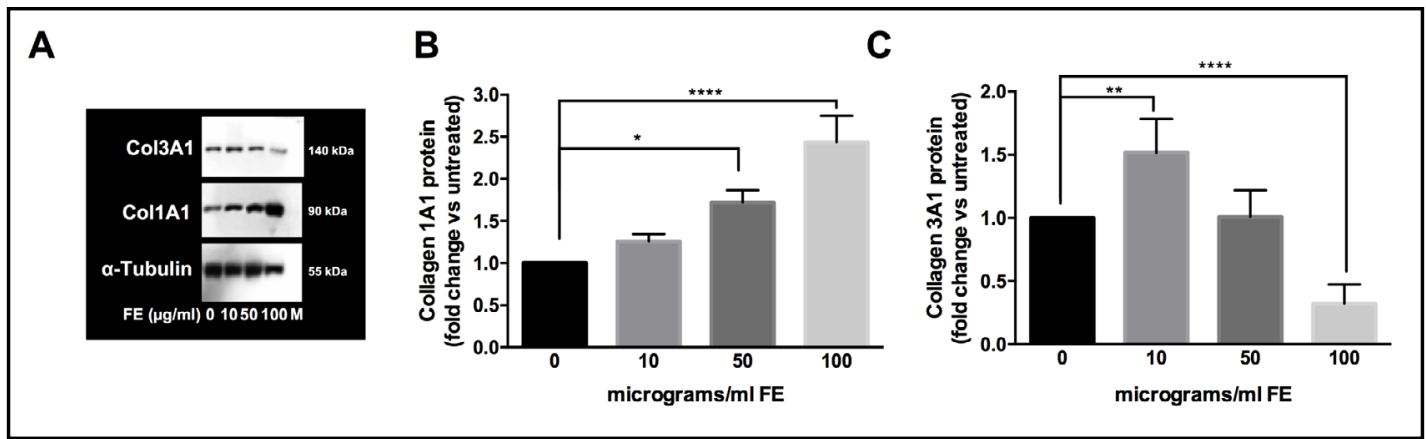

Fig. 6. Detection of Col1A1 and Col3A1 proteins in lung fibroblasts exposed or not to fluoro-edenite (FE) for 72 hours. Representative Immunoblot of Col1A1 and Col3A1 (A). Representation of three independent immunoblots as fold change of Col1A1 (B) and Col3A1 (C) expression with respect to control. For statistical significance one-way ANOVA followed by Dunnett's multiple comparisons test was performed to underscore difference with respect to basal condition ( $\mathrm{n}=3{ }^{*} \mathrm{p}<0.05$, $\left.{ }^{* *} \mathrm{p}<0.01 ;{ }^{* * *} \mathrm{p}<0.005\right)$.

Table 3. MMP1 and MMP3 mRNA in lung fibroblasts after treatment with 10,50,100 $\mu \mathrm{g} / \mathrm{ml}$ of fluoro-edenite for 72 hours. The mRNA expression was normalized to the housekeeping gene GAPDH for absolute level $(2-\Delta \mathrm{C} t)$ and to the untreated control for relative level $(2-\Delta \Delta \mathrm{Ct}$ method). For statistical significance treated and untreated conditions were matched by ANOVA and Bonferroni's multiple comparisons test $\left({ }^{*} \mathrm{p}<0.05\right)$.

\begin{tabular}{|c|c|c|c|c|c|c|c|}
\hline \multirow{3}{*}{ Primer } & \multicolumn{7}{|c|}{ mRNA expression level of MMPs } \\
\hline & \multicolumn{4}{|c|}{$\begin{array}{c}\text { Absolute } \\
\text { (2- }-\Delta \Delta \text { Ct normalized to GAPDH) }\end{array}$} & \multicolumn{3}{|c|}{$\begin{array}{c}\text { Relative } \\
(2-\Delta \Delta \mathrm{Ct} \text { normalized to untreated })\end{array}$} \\
\hline & $\begin{array}{c}0 \mu \mathrm{g} / \mathrm{ml} \\
\text { fluoro-edenite }\end{array}$ & $\begin{array}{c}10 \mu \mathrm{g} / \mathrm{ml} \\
\text { fluoro-edenite }\end{array}$ & $\begin{array}{c}50 \mu \mathrm{g} / \mathrm{ml} \\
\text { fluoro-edenite }\end{array}$ & $\begin{array}{c}100 \mu \mathrm{g} / \mathrm{ml} \\
\text { fluoro-edenite }\end{array}$ & $\begin{array}{c}10 \mu \mathrm{g} / \mathrm{ml} \\
\text { fluoro-edenite }\end{array}$ & $\begin{array}{c}50 \mu \mathrm{g} / \mathrm{ml} \\
\text { fluoro-edenite }\end{array}$ & $\begin{array}{c}100 \mu \mathrm{g} / \mathrm{ml} \\
\text { fluoro-edenite }\end{array}$ \\
\hline MMP1 & $0.67 \pm 0.12$ & $0.74 \pm 0.09$ & $1.8 \pm 0.25$ & $0.53 \pm 0.08$ & $1.1 \pm 0.12$ & $2.6 \pm 0.37$ & $0.79 \pm 0.12$ \\
\hline MMP3 & $0.053 \pm 0.005$ & $0.061 \pm 0.009$ & $0.086 \pm 0.05$ & $0.51 \pm 0.08$ & $1.15 \pm 0.17$ & $1.6 \pm 0.9$ & $9.6 \pm 1.5^{*}$ \\
\hline
\end{tabular}

Fig. 7. Levels of (A) MMP1 and (B) MMP3 in lung fibroblasts exposed or not to fluoro-edenite (FE) for 72 hours. Representative Immunoblot of MMP1 (A1) and MMP3 (B3). Release in culture medium reported as fold change of MMP1 (A2) and MMP3 (B2) with respect to control. For statistical significance one-way ANOVA followed by Dunnett's multiple comparisons test $\left(\mathrm{n}=3\right.$; $\left.^{*} \mathrm{p}<0.05\right)$.
A1

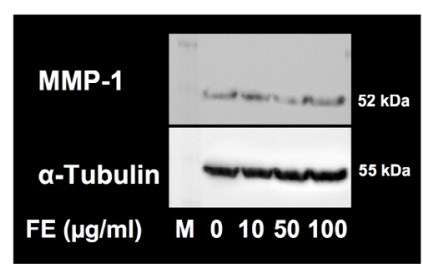

B1

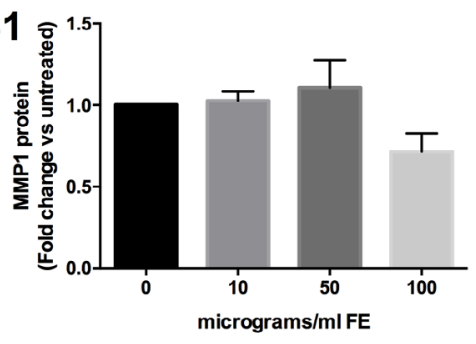

A2

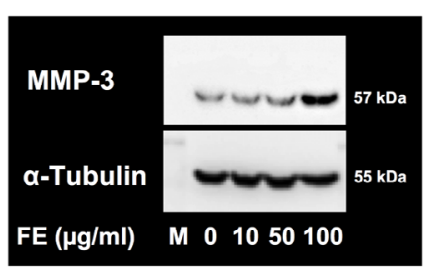

B2

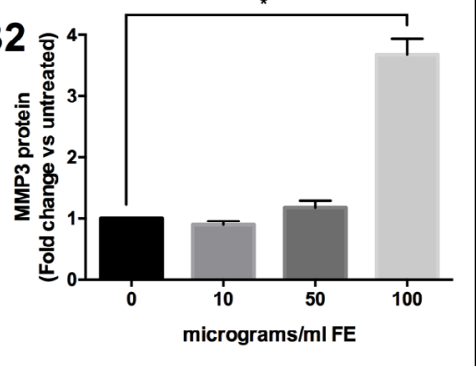




\section{Cellular Physiology Cell Physiol Biochem 2021;55:327-343 \begin{tabular}{ll|l} 
and Biochemistry & $\begin{array}{l}\text { DOl 10.33594/000000379 } \\
\text { Published online: 23 June 2021 }\end{array}$ & $\begin{array}{l}\text { O 2021 The Author(s). Published by } \\
\text { Cell Physiol Biochem Press GmbH\&Co. KG }\end{array}$ \\
\cline { 2 - 3 } &
\end{tabular}

Fig. 8. Effects of MMP3 inhibition on collagens content and cell senescence. (A) Representative immunoblot of Col1A1 and Col3A1 (B) Senescenceassociated $\beta$-galactosidase (SA- $\beta$-Gal) activity was expressed as relative fluorescent units (R.F.U.) \pm SEM after normalization to total protein content for each sample. Two-way ANOVA followed by Sidak's multiple comparisons test was performed to analyze difference between the MMP3-inhibited groups and the same experimental condition without MMP3 inhibitor $\left(\mathrm{n}=3 ;{ }^{*} \mathrm{p}<0.05\right)$.

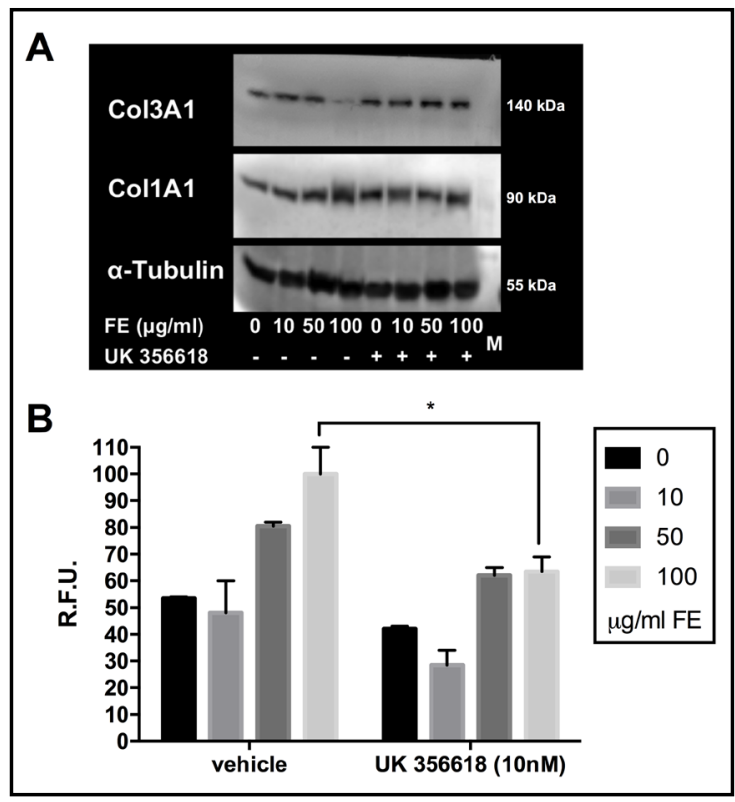

\section{Discussion}

In this in vitro work, we found that the senescence of pulmonary fibroblasts could be considered an early program of adaptation established during the exposure to the environmental pollutant fluoro-edenite.

It is known that the homeostasis and the development of disorders of lung cells can be affected by external stimuli that reach the tissue through the inspired air. It has been described for exposure (i) to acrolein present in wood smoke, diesel exhaust, cooking oil fume, and smog [36, 37]; (ii) to polyolefin composed of polypropylene [38, 39]; and (iii) to asbestos and fibers in general $[40,41]$.

Here, we focus on mitochondrial activity, apoptosis activation, senescence, growth and migration of well-characterized lung fibroblasts (elongated spindle-shaped, positive to vimentin and $\mathrm{P} 4 \mathrm{HB}$, and negative to desmin and CD31), even if the concept of lung fibroblasts heterogeneity is long-time known [42-46]. Our data analysis suggested that the functions of mitochondrial dehydrogenase enzymes are reduced in a time- and concentration-dependent manner. Results are in line with a previous report [22]. MTT assay is an indirect tool to measure cell viability, and the effect measured could primarily reflect growth inhibition and not loss of viability [47]. Therefore, we analyzed the apoptosis activation. In some previous studies on sheep, in fact, it was reported that fluoro-edenite fibers induce lung cell apoptosis [48] and that the altered balance between $\mathrm{pRb}$ and $\mathrm{Rb}$ expression may be a programmed response to protect the organism against uncontrolled cell proliferation [49]. On the contrary, our results reveal a resistance to apoptosis that could be explained by cellular senescence, commonly known as the physiological process that is essential in vivo and typical for normal human cells in vitro, especially for primary culture [50]. Since the senescence of fibroblasts increases in control condition following in vitro division, we used only cells at a passage earlier than the tenth to avoid significant difference of senescence at basal level. We found a stronger senescence induction after the incubation with fluoroedenite at higher concentration. As reviewed by Rodier and Campisi [51], the physiological relevance of senescence could have multifaceted aspect, participating at least in four complex biological events that could mediate opposing effects: tumor suppression, tumor promotion, aging, and tissue repair. Within an injured tissue, senescence may affect the capacity for beneficial versus deleterious consequences [52]. 


\section{Cellular Physiology Cell Physiol Biochem 2021;55:327-343

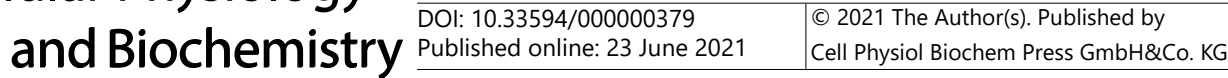

As about fluoro-edenite and according to literature data reported above, it could modulate both tumor promotion and aging. Even if this is the first work evaluating a fluoroedenite-induced senescence, the reports that found an increased release of IL- 6 and IL-8 $[15,16,53]$ could be justified by a senescent phenotype. These cytokines, in fact, have been reported to be secreted by senescent cells to drive the invasion of basement membrane of premalignant and weakly malignant epithelial cells [54].

As about fibroblasts, we performed the in vitro scratch assay coupled with the crystal violet staining as an easy, low-cost and well-developed method to measure simultaneously cell migration and live cells. Results suggested a down-regulation of cell growth, the loss of cell-cell interactions with morphological changes. In order to investigate better these events, we analyzed the molecular composition of ECM, considering that it is an active element for the cell behavior to guarantee the physiological function of the lung [55], and for the cell migratory paths [56]. As reviewed by White [57], the behavior of fibroblasts influences ECM composition and, in the meantime, the ECM modulates the phenotype, and the shape of interstitial fibroblasts [34, 35, 58, 59-66].

The ECM is as an ordered aggregate of macromolecules. It is composed by different types of collagens, fibronectin, and proteoglycans. About its functional properties, the ECM not only maintains geometry and structural integrity of various organs and tissues, but also supports fibroblasts homeostasis providing mediators of cell-ECM signaling. These factors seem to act on cell-cell interactions, proliferation, and migration, leading to the hypothesis that ECM is not just a scaffold or an endpoint of fibroblasts activity, but also a key element to assess lung physiology. To date, an elegant evidence of this phenomenon has been published by Marinković et al. [67]. Moreover, the dynamic biology of ECM reflects the activity of fibroblasts that orchestrate synthesis and deposition of ECM products, and their turnover. This latter configures as a degradation step mediated by secretion of ECM-degrading enzymes, named matrix metalloproteinase (MMPs).

The MMPs family consists of zinc-dependent endopeptidases acting in extracellular milieu [68] to breakdown macromolecules of the ECM system. Each member shows substrate specificity and, according to this aspect, four main groups of MMPs have been identified: collagenases, gelatinases, stromelysins, and membrane-type MMPs. MMPs work synergically: collagens are fragmented by collagenases into gelatins. These latter are substrates of gelatinases that produce single amino acids or oligopeptides. The stromelysins are capable of degrading proteoglycan, fibronectin, laminin, and collagens, but not interstitial type I collagen. Some evidences demonstrated that the ECM-cell interactions might be extremely tissue-specific [69].

In this study, the versican, the Col1A1, and the Col3A1 content was evaluated because: (i) the large chondroitin sulfate proteoglycan versican is physiologically produced by lung fibroblasts [70], and (ii) fibrillar collagens 1 and 3 have been reported on lung parenchyma [71]. Versican seems to be involved in lung inflammation [57, 72, 73] and, in our experimental condition, versican levels were upregulated while cell migratory properties decreased, similarly to previously reported data [74]. Moreover, the versican augmented level could act as a potent trigger for activation of fibroblasts in inflammation, suggesting it as an evaluable molecular link between inflammation and cancer due to its ligation to Tolllike receptor 2 [75]. Four isoforms of versican have been reported: V0, V1, V2, and V3 [76, 77] that are differently expressed: $\mathrm{V} 1 / \mathrm{V} 0$ in the late stages of embryonic development [78], and V2 in the mature brain [79]. Our primers were for the V1 isoform, expressed by lung fibroblasts in vitro [80]. The upregulation of V1 isoform in our system strongly suggested a mechanism of adaptation to low dose of fibers that could escape the homeostatic control at higher fluoro-edenite levels.

As about collagens, we found significant decreases in amount of Col3A1 and a doubled quantity of Col1A1 after $100 \mu \mathrm{g} / \mathrm{ml}$ of fluoro-edenite exposure. In this condition, the ratio of Col1A1:Col3A1 was of 4:1, indeed it was constant up to $50 \mu \mathrm{g} / \mathrm{ml}$ of fluoro-edenite incubation with respect to unexposed cells. To date, increasing levels of Col1A1, concomitantly at decrease of Col1A3, have been historically associate to human respiratory distress 


\section{Cellular Physiology Cell Physiol Biochem 2021;55:327-343 \\ \begin{tabular}{ll|l} 
and Biochemistry $\begin{array}{l}\text { DOl: 10.33594/000000379 } \\
\text { Published online: 23 June 2021 }\end{array}$ & $\begin{array}{l}\text { O } 2021 \text { The Author(s). Published by } \\
\text { Cell Physiol Biochem Press GmbH\&Co. KG }\end{array}$ \\
\cline { 2 - 3 } & Gat
\end{tabular} \\ Graziano et al.: Fluoro-Edenite on Human Fibroblasts}

syndrome [81], and to idiopathic pulmonary fibrosis [82], suggesting an ECM remodeling. Therefore, we evaluated the ECM degrading enzyme MMP1, MMP3, and MMP13. We found no significant difference for MMP1 levels, whereas increasing mRNA, protein and secretion of MMP3 after $100 \mu \mathrm{g} / \mathrm{ml}$ of fluoro-edenite exposure with respect to unexposed controls. According to these findings, we can speculate that MMP3 increase should be associated to a senescent phenotype as reported by another in vitro study on human aged-fibroblasts [83]. This event may inhibit the morphological and functional differentiation of epithelial cells, as already reported for epithelial breast cell [84], promoting the development of an environment recognized useful for tumor growth [85]. Considering our system, especially in presence of the MMP3 inhibitor, we can consider MMP3 as a key element of ECM homeostatic control in relation to both the physiological senescence of cells in vitro and that one induced by fluoroedenite. Even if MMP3 amino acid sequence in humans is 55\% identical with MMP-1, they have different substrate specificity [86]. MMP3 is not able to cleave triple-helical region of type 1 and 2 collagens, while a weak activity was reported on type 3 collagen. Moreover, MMP3 participates in activation of pro-MMP1. Human MMP1 degrades human collagens 3, 1 , and 2 with decreasing preference, respectively. Remarkably, in our experimental setting, MMP1 levels remained constant, supposing a feedback loop between ECM and enzyme synthesis. Specifically, up to the ratio of Col1A1:Col3A1 remained constant and physiological respect to controls, the MMP3 release was unmodified. The higher level of fluoro-edenite produced senescence with release of MMP3, inducing the degradation of Col3A1. In future, we propose to explain better if this event may be a positive feedback loop for MMP1 and MMP3 release in longer stimulations both in vitro and in vivo. Especially, it could be useful the evaluation of the activity of the enzyme P4-HB, that is required to stabilize the triple helical conformation of Col1A1, by using molecular oxygen and ferrous ion to catalyze the hydroxylation.

\section{Conclusion}

The major novel finding in these experiments is that lung fibroblasts adapt to fluoroedenite by the instauration of a senescent phenotype from mild to severe. The fluoro-edenitetreated senescent lung fibroblasts produce changes in the levels of versican, collagens and MMP3 as molecular mechanisms that alter ECM. These events can give rise to profibrotic cellular phenotypes and oncogenic microenvironment. The induction of premature senescent phenotype process could be a preclinical evidence of pathogenesis of mesothelioma, for this reason is hopefully to identify preclinical biomarkers for population exposed to asbestiform fibers [87-89]. In any case, our findings certainly provide new insights into the understanding between environmental pollutants and human health.

\section{Acknowledgements}

We give our thanks to Professor Carlo Vancheri (University of Catania) for the donation of primary fibroblasts.

\section{Author Contributions}

ACEG: Conceptualization, Methodology, Investigation, Writing - original Draft, Visualization; CL: methodology, Investigation; CL: Investigation; VC: Conceptualization, Validation, Writing-Review \& Editing, Supervision, Funding acquisition.

\section{Funding Sources}

This study was partially supported by University of Catania (Italy) (grant numbers: 20722142130 and 20722142115). 


\section{Cellular Physiology Cell Physiol Biochem 2021;55:327-343

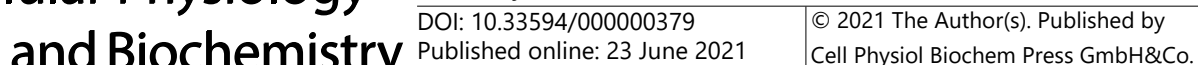 \\ Graziano et al.: Fluoro-Edenite on Human Fibroblasts}

Statement of Ethics

The authors have no ethical conflicts to disclose.

\section{Disclosure Statement}

The authors have no conflicts of interest to declare.

\section{References}

1 Bruno C, Comba P, Zona A: Adverse health effects of fluoro-edenitic fibers: epidemiological evidence and public health priorities. Ann NY Acad Sci 2006;1076:778-783.

2 Comba P, Gianfagna A, Paoletti L: Pleural mesothelioma cases in Biancavilla are related to a new fluoroedenitefibrous amphibole. Arch Environ Health 2003;58:229-232.

3 Ballan G, Del Brocco A, Loizzo S, Fabbri A, Maroccia Z, Fiorentini C, Travaglione S: Mode of action of fibrous amphiboles: the case of Biancavilla (Sicily, Italy). Ann Ist Super Sanità 2014;50:133-138.

4 Bruni BM, Soggiu ME, Marsili G, Brancato A, Inglessis M, Palumbo L, Piccardi A, Beccaloni E, Falleni F, Mazziotti Tagliani S, Pacella A: Environmental concentrations of fibers with fluoro-edenitic composition and population exposure in Biancavilla (Sicily, Italy). Ann Ist Super Sanità 2014;50:119-126.

5 Bruno C, Tumino R, Fazzo L, Cascone G, Cernigliaro A, De Santis M, Giurdanella MC, Nicita C, Rollo PC, Scondotto S, Spata E, Zona A, Comba, P: Incidence of pleural mesothelioma in a community exposed to fibres with fluoro-edenitic composition in Biancavilla (Sicily, Italy). Ann Ist Super Sanità 2014;50:111-118.

6 Comba P, Scondotto S, Musmeci L: The fibres with fluoro-edenitic composition in Biancavilla (Sicily, Italy): health impact and clues for environmental remediation. Ann Ist Super Sanità 2014;50:108-110.

7 Conti S, Minelli G, Manno V, Iavarone I, Comba P, Scondotto S, Cernigliaro A: Health impact of the exposure to fibres with fluoro-edenitic composition on the residents in Biancavilla (Sicily, Italy): mortality and hospitalization from current data. Ann Ist Super Sanità 2014;50:127-132.

8 World Health Organization, International Agency for Research on Cancer: Some Nanomaterials and Some Fibres, Volume 111. IARC Monographs on the Evaluation of Carcinogenic Risks to Humans. Chapter: Fluoro-Edenite. Lyon, France, 2017, pp 215-242.

9 Grosse Y, Loomis D, Guyton KZ, Lauby-Secretan B, El Ghissassi F, Bouvard V, Benbrahim-Tallaa L, Guha N, Scoccianti C, Mattock H, Straif K: Carcinogenicity of fluoro-edenite, silicon carbide fibres and whiskers, and carbon nanotubes. Lancet Oncol 2014;15:1427-1428.

10 Fazzo L, Minelli G, De Santis M, Bruno C, Zona A, Conti S, Comba P: Epidemiological surveillance of mesothelioma mortality in Italy. Cancer Epidemiol 2018;55:184-191.

11 Rapisarda V, Ledda C, Ricceri V, Arena F, Musumeci A, Marconi A, Fago L, Bracci M, Santarelli L, Ferrante M: Detection of pleural plaques in workers exposed to inhalation of natural fluoro-edenite fibres. Oncol Lett 2015;9:2046-2052.

12 Soffritti M, Minardi F, Bua L, Degli Esposti D, Belpoggi F: First experimental evidence of peritoneal and pleural mesotheliomas induced by fluoro-edenite fibres present in Etnean volcanic material from Biancavilla (Sicily, Italy). Eur J Oncol 2014;9:169-175.

13 Musumeci G, Loreto C, Szychlinska MA, Imbesi R, Rapisarda V, Aiello FC, Castorina S, Castrogiovanni P: N-Cadherin, ADAM-10 and Aquaporin 1 expression in lung tissue exposed to fluoro-edenite fibers: an immunohistochemical study. Histol Histopathol 2015;30:987-999.

14 Musumeci G, Loreto C, Giunta S, Rapisarda V, Szychlinska MA, Imbesi R, Castorina A, Annese T, Castorina S, Castrogiovanni P, Ribatti D: Angiogenesis correlates with macrophage and mast cell infiltration in lung tissue of animals exposed to fluoro-edenite fibers. Exp Cell Res 2016;346:91-98.

15 Travaglione S, Bruni B, Falzano L, Paoletti L, Fiorentini C: Effects of the new-identified amphibole fluoroedenite in lung epithelial cells. Toxicol In vitro 2003;17:547-552.

16 Travaglione S, Bruni BM, Falzano L, Filippini P, Fabbri A, Paoletti L, Fiorentini C: Multinucleation and proinflammatory cytokine release promoted by fibrous fluoro-edenite in lung epithelial A549 cells. Toxicol In vitro 2006;20:841-850. 


\section{Cellular Physiology Cell Physiol Biochem 2021;55:327-343 and Biochemistry DOl: 10.33594/000000379 202021 The Author(s). Published by and Biochemistry Published online: 23 June 2021 Cell Physiol Biochem Press GmbH\&Co. KG

17 Loreto C, Carnazza ML, Cardile V, Libra M, Lombardo L, Malaponte G, Martinez G, Musumeci G, Papa V, Cocco L: Mineral fiber-mediated activation of phosphoinositide-specific phospholipase $c$ in human bronchoalveolar carcinoma-derived alveolar epithelial A549 cells. Int J Oncol 2009;34:371-376.

18 Musumeci G, Cardile V, Fenga C, Caggia S, Loreto C: Mineral fibre toxicity: expression of retinoblastoma $(\mathrm{Rb})$ and phospho-retinoblastoma ( $\mathrm{pRb}$ ) protein in alveolar epithelial and mesothelial cell lines exposed to fluoro-edenite fibres. Cell Biol Toxicol 2011;27:217-225.

19 Pugnaloni A, Lucarini G, Giantomassi F, Lombardo L, Capella S, Belluso E, Zizzi A, Panico AM, Biagini G, Cardile V: In vitro study of biofunctional indicators after exposure to asbestos-like fluoro-edenite fibres. Cell Mol Biol (Noisy-le-grand) 2007;53:OL965-980.

20 Cardile V, Proietti L, Panico A, Lombardo L: Nitric oxide production in fluoro-edenite treated mouse monocyte-macrophage cultures. Oncol Rep 2004;12:1209-1215.

21 Cardile V, Lombardo L, Belluso E, Panico A, Renis M, Gianfagna A, Balazy M: Fluoro-edenite fibers induce expression of Hsp70 and inflammatory response. Int J Environ Res Public Health 2007;4:195-202.

22 Cardile V, Renis M, Scifo C, Lombardo L, Gulino R, Mancari B, Panico A: Behaviour of the new asbestos amphibole fluor-edenite in different lung cell systems. Int J Biochem Cell Biol 2004;36:849-860.

23 Rapisarda V, Caltabiano R, Musumeci G, Castrogiovanni P, Ferrante M, Ledda C, Lombardo C, Graziano ACE, Cardile V, Loreto C: Analysis of fibulin-3 after exposure to asbestos-like fibers. Environ Res 2017;156:381387.

24 Rapisarda V, Salemi R, Marconi A, Loreto C, Graziano AC, Cardile V, Basile MS, Candido S, Falzone L, Spandidos DA, Fenga C, Libra M: Fluoro-edenite induces fibulin-3 overexpression in non-malignant human mesothelial cells. Oncol Lett 2016;12:3363-3367.

25 Loreto C, Caltabiano R, Graziano ACE, Castorina S, Lombardo C, Filetti V, Vitale E, Rapisarda G, Cardile V, Ledda C, Rapisarda V: Defense and protection mechanisms in lung exposed to asbestiform fiber: the role of macrophage migration inhibitory factor and heme oxygenase-1. Eur J Histochem 2020;64:3073.

26 Roomans GM: Tissue engineering and the use of stem/progenitor cells for airway epithelium repair. Eur Cell Mater 2010;19:284-299.

27 Graziano AC, Cardile V, Avola R, Vicario N, Parenti C, Salvatorelli L, Magro G, Parenti R: Wilms' tumor gene 1 silencing inhibits proliferation of human osteosarcoma MG-63 cell line by cell cycle arrest and apoptosis activation. Oncotarget 2017;8:13917-13931.

28 Parenti R, Cardile V, Graziano AC, Parenti C, Venuti A, Bertuccio MP, Lo Furno D, Magro G, Wilms' tumor gene 1 (WT1) silencing inhibits proliferation of malignant peripheral nerve sheath tumor sNF96.2 cell line. PLoS One 2014;9:e114333.

29 Graziano ACE, Pannuzzo G, Salemi E, Santagati A, Avola R, Longo E, Cardile V: Synthesis, characterization, molecular modeling, and biological evaluation of thieno-pyrimidinone methanesulphonamide thioderivatives as nonsteroidal anti-inflammatory agents. Clin Exp Pharmacol Physiol 2018;7:197.

30 Avola R, Granata G, Geraci C, Napoli E, Graziano ACE, Cardile V: Oregano (Origanum vulgare L.) essential oil provides anti-inflammatory activity and facilitates wound healing in a human keratinocytes cell model [published online ahead of print, Food Chem Toxicol 2020;144:111586.

31 Liang CC, Park AY, Guan JL: In vitro scratch assay: a convenient and inexpensive method for analysis of cell migration in vitro. Nat Protoc 2007;2:329-333

32 Chen HY, Huang TC, Lin LC, Shieh TM, Wu CH, Wang KL, Hong YH, Hsia SM: Fucoidan Inhibits the Proliferation of Leiomyoma Cells and Decreases Extracellular Matrix-Associated Protein Expression. Cell Physiol Biochem 2018;49:1970-1986.

33 Graziano AC, Parenti R, Avola R, Cardile V: Krabbe disease: involvement of connexin 43 in the apoptotic effects of sphingolipid psychosine on mouse oligodendrocyte precursors. Apoptosis 2016;21:25-35.

34 Graziano ACE, Avola R, Pannuzzo G, Cardile V: Aquaporin1 and 3 modification as a result of chondrogenic differentiation of human mesenchymal stem cell. J Cell Physiol 2018;233:2279-2291.

35 Avola R, Graziano ACE, Pannuzzo G, Albouchi F, Cardile V: New insights on Parkinson's disease from differentiation of SH-SY5Y into dopaminergic neurons: An involvement of aquaporin4 and 9. Mol Cell Neurosci 2018;88:212-221.

36 Deshmukh HS, Shaver C, Case LM, Dietsch M, Wesselkamper SC, Hardie WD, Korfhagen TR, Corradi M, Nadel JA, Borchers MT, Leikauf GD: Acrolein-activated matrix metalloproteinase 9 contributes to persistent mucin production. Am J Respir Cell Mol Biol 2008;38:446-454. 


\section{Cellular Physiology Cell Physiol Biochem 2021;55:327-343

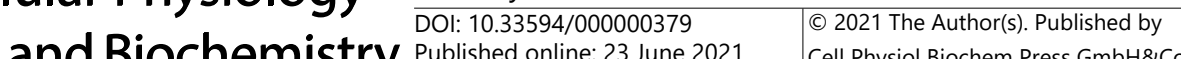 and Biochemistry Published online: 23 June 2021 Cell Physiol Biochem Press GmbH\&Co. KG \\ Graziano et al.: Fluoro-Edenite on Human Fibroblasts}

37 Leikauf GD, Borchers MT, Prows DR, Simpson LG: Mucin apoprotein expression in COPD. Chest 2002;121:166S-182S.

38 Hesterberg TW, McConnell EE, Miiller WC, Hamilton R, Bunn WB: Pulmonary toxicity of inhaled polypropylene fibers in rats. Fundam Appl Toxicol 1992;19:358-366.

39 Warheit DB, Webb TR, Reed KL, Hansen JF, Kennedy GL Jr: Four-week inhalation toxicity study in rats with nylon respirable fibers: rapid lung clearance. Toxicology 2003;192:189-210.

40 Mossman BT, Shukla A, Heintz NH, Verschraegen CF, Thomas A, Hassan R: New insights into understanding the mechanisms, pathogenesis, and management of malignant mesotheliomas. Am J Pathol 2013;182:1065-1077.

41 Røe OD, Stella GM: Malignant pleural mesothelioma: history, controversy and future of a manmade epidemic. Eur Respir Rev 2015;24:115-131.

42 Derdak S, Penney DP, Keng P, Felch ME, Brown D, Phipps RP: Differential collagen and fibronectin production by Thy $1^{+}$and Thy $1^{-}$lung fibroblast subpopulations. Am J Physiol 1992;263:L283-L290.

43 Phipps RP, Penney DP, Keng P, Quill H, Paxhia A, Derdak S, Felch ME: Characterization of two major populations of lung fibroblasts: distinguishing morphology and discordant display of Thy 1 and class II MHC. Am J Respir Cell Mol Biol 1989;1:65-74.

44 Phipps RP, Penney DP, Keng P, Silvera M, Harkins S, Derdak S: Immune functions of subpopulations of lung fibroblasts. Immunol Res 1990;9:275-286.

45 Wong T, McGrath JA, Navsaria H: The role of fibroblasts in tissue engineering and regeneration. Br J Dermatol 2007;156:1149-1155.

46 Sorrell JM, Caplan AI: Fibroblast heterogeneity: more than skin deep. J Cell Sci 2004;117: 667-675.

47 Rai Y, Pathak R, Kumari N, Sah DK, Pandey S, Kalra N, Soni R, Dwarakanath BS, Bhatt AN: Mitochondrial biogenesis and metabolic hyperactivation limits the application of MTT assay in the estimation of radiation induced growth inhibition. Sci Rep 2018;8:1531.

48 Loreto C, Rapisarda V, Carnazza ML, Musumeci G, Valentino M, Fenga C, Martinez G: Fluoro-edenite fibres induce lung cell apoptosis: an in vivo study. Histol Histopathol 2008;23:319-326.

49 Musumeci G, Loreto C, Cardile V, Carnazza ML, Martinez,G: Immunohistochemical expression of retinoblastoma and phospho-retinoblastoma protein in sheep lung exposed to fluoro-edenite fibers. Anat Sci Int 2010;85:74-78.

50 Hayflick L: The limited in vitro lifetime of human diploid cell strains. Exp Cell Res 1965;37:614-636.

51 Rodier F, Campisi J: Four faces of cellular senescence. J Cell Biol 2011;192:547-556.

52 He Y, Thummuri D, Zheng G, Okunieff P, Citrin DE, Vujaskovic Z, Zhou D: Cellular senescence and radiationinduced pulmonary fibrosis. Transl Res 2019;209:14-21.

53 Ledda C, Costa C, Matera S, Puglisi B, Costanzo V, Bracci M, Fenga C, Rapisarda V, Loreto C: Immunomodulatory effects in workers exposed to naturally occurring asbestos fibers. Mol Med Rep 2017;15:3372-3378.

54 Coppé JP, Patil CK, Rodier F, Krtolica A, Beauséjour CM, Parrinello S, Hodgson JG, Chin K, Desprez PY, Campisi J: A human-like senescence-associated secretory phenotype is conserved in mouse cells dependent on physiological oxygen. PLoS One 2010;5:e9188.

55 Wight TN, Frevert CW, Debley JS, Reeves SR, Parks WC, Ziegler SF: Interplay of extracellular matrix and leukocytes in lung inflammation. Cell Immunol 2017;312:1-14.

56 Salmon H, Franciszkiewicz K, Damotte D, Dieu-Nosjean MC, Validire P, Trautmann A, Mami-Chouaib F, Donnadieu E: Matrix architecture defines the preferential localization and migration of $\mathrm{T}$ cells into the stroma of human lung tumors. J Clin Invest 2012;122:899-910.

57 White ES: Lung extracellular matrix and fibroblast function. Ann Am Thorac Soc 2015;12:S30-S33.

58 Cukierman E: Cell migration analyses within fibroblast-derived 3-D matrices. Methods Mol Biol 2005; 294: 79-93.

59 Graziano ACE, Avola R, Perciavalle V, Nicoletti F, Cicala G, Coco M, Cardile V: Physiologically based microenvironment for in vitro neural differentiation of adipose-derived stem cells. World J Stem Cells 2018;10:23-33.

60 Johnson LA, Rodansky ES, Sauder KL, Horowitz JC, Mih JD, Tschumperlin DJ, Higgins PD: Matrix stiffness corresponding to strictured bowel induces a fibrogenic response in human colonic fibroblasts. Inflamm Bowel Dis 2013;19:891-903. 


\section{Cellular Physiology Cell Physiol Biochem 2021;55:327-343 \begin{tabular}{c|c|c|c|} 
DOI: $10.33594 / 000000379$ & () 2021 The Author(s). Published by
\end{tabular} and Biochemistry Published online: 23 June 2021 Cell Physiol Biochem Press GmbH\&Co. KG

61 Mao Y, Schwarzbauer JE: Stimulatory effects of a three-dimensional microenvironment on cell-mediated fibronectin fibrillogenesis. J Cell Sci 2005;118:4427-4436.

62 Poobalarahi F, Baicu CF, Bradshaw AD: Cardiac myofibroblasts differentiated in 3d culture exhibit distinct changes in collagen production, processing, and matrix deposition. Am J Physiol Heart Circ Physiol 2006;291:H2924-H2932.

63 Saums MK, Wang W, Han B, Madhavan L, Han L, Lee D, Wells RG: Mechanically and chemically tunable cell culture system for studying the myofibroblast phenotype. Langmuir 2014;30:5481-5487.

64 Schrader J, Gordon-Walker TT, Aucott RL, van Deemter M, Quaas A, Walsh S, Benten D, Forbes SJ, Wells RG, Iredale JP: Matrix stiffness modulates proliferation, chemotherapeutic response, and dormancy in hepatocellular carcinoma cells. Hepatology 2011;53:1192-1205.

65 Tilghman RW, Blais EM, Cowan CR, Sherman NE, Grigera PR, Jeffery ED, Fox JW, Blackman BR, Tschumperlin DJ, Papin JA, Parsons JT: Matrix rigidity regulates cancer cell growth by modulating cellular metabolism and protein synthesis. PLoS One 2012;7:e37231.

66 Tschumperlin DJ, Liu F, Tager AM: Biomechanical regulation of mesenchymal cell function. Curr Opin Rheumatol 2013;25:92-100.

67 Marinković A, Liu F, Tschumperlin DJ: Matrices of physiologic stiffness potently inactivate idiopathic pulmonary fibrosis fibroblasts. Am J Respir Cell Mol Biol 2013;48:422-430.

68 Birkedal-Hansen H, Moore WG, Bodden MK, Windsor LJ, Birkedal-Hansen B, De Carlo A, Engler JA: Matrix metalloproteinases: a review. Crit Rev Oral Biol Med 1993;4:197-250.

69 Lindner D, Zietsch C, Becher PM, Schulze K, Schultheiss HP, Tschope C, Westermann D: Differential expression of matrix metalloproteases in human fibroblasts with different origins. Biochem Res Int 2012;2012:875742.

70 Zimmermann DR, Ruoslahti E: Multiple domains of the large fibroblast proteoglycan, versican. EMBO J 1989;8:2975-2981.

71 van Kuppevelt TH, Veerkamp JH, Timmermans JAH: Immunoquantification of type I, III, IV and V collagen in small samples of human lung parenchyma. Int J Biochem Cell Biol 1995;27:775-782.

72 Andersson-Sjöland A, Hallgren O, Rolandsson S, Weitoft M, Tykesson E, Larsson-Callerfelt AK, RydellTörmänen K, Bjermer L, Malmström A, Karlsson JC, Westergren-Thorsson G: Versican in inflammation and tissue remodeling: the impact on lung disorders. Glycobiol 2015;25:243-251.

73 Wight TN, Kang I, Merrilees MJ: Versican and the control of inflammation. Matrix Biol 2014;35:152-161.

74 Andersson-Sjöland A, Thiman L, Nihlberg K, Hallgren O, Rolandsson S, Skog I, Mared L, Hansson L, Eriksson L, Bjermer L, Westergren-Thorsson G: Fibroblast phenotypes and their activity are changed in the wound healing process after lung transplantation. J Heart Lung Transplant 2011;30:945-954.

75 Wang W, Xu GL, Jia WD, Ma JL, Li JS, Ge YS, Ren WH, Yu JH, Liu WB: Ligation of TLR2 by versican: A link between inflammation and metastasis. Arch Med Res 2009;40:321-323.

76 Ito K, Shinomura T, Zako M, Ujita M, Kimata K: Multiple forms of mouse PG-M, a large chondroitin sulfate proteoglycan generated by alternative splicing. J Biol Chem 1995;270:958-965.

77 Lemire JM, Braun KR, Maurel P, Kaplan ED, Schwartz SM, Wight TN: Versican/PG-M isoforms in vascular smooth muscle cells. Arterioscler Thromb Vasc Biol 1999;19:1630-1639.

78 Landolt RM, Vaughan L, Winterhalter KH, Zimmermann DR: Versican is selectively expressed in embryonic tissues that act as barriers to neural crest cell migration and axon outgrowth. Development 1995;121:3032312.

79 Schmalfeldt M, Dours-Zimmermann MT, Winterhalter KH, Zimmermann DR: Versican V2 is a major extracellular matrix component of the mature bovine brain. J Biol Chem 1998;273:15758-15764.

80 Wu L, Zhang J, Qu JM, Bai CX, Merrilees MJ: Deposition of insoluble elastin by pulmonary fibroblasts from patients with COPD is increased by treatment with versican siRNA. Int J Chron Obstruct Pulmon Dis 2017;12:267-273.

81 Last JA, Siefkin AD, Reiser KM: Type I collagen content is increased in lungs of patients with adult respiratory distress syndrome. Thorax 1976;38:364-368.

82 Seyer JM, Hutcheson ET, Kang AH: Collagen polymorphism in idiopathic chronic pulmonary fibrosis. J Clin Invest 1976;57:1498-1507.

83 Millis AJ, Hoyle M, McCue HM, Martini H: Differential expression of metalloproteinase and tissue inhibitor of metalloproteinase genes in aged human fibroblasts. Exp Cell Res 1992;201:373-379. 
84 Parrinello S, Coppe JP, Krtolica A, Campisi J: Stromal-epithelial interactions in aging and cancer: senescent fibroblasts alter epithelial cell differentiation. J Cell Sci 2005;118:485-496.

85 Liu D, Hornsby PJ: Senescent human fibroblasts increase the early growth of xenograft tumors via matrix metalloproteinase secretion. Cancer Res 2007;67:3117-3126.

86 Nagase H: Substrate Specificity of MMPs; in Clendeninn NJ, Appelt K, Totowa NJ (eds): Matrix Metalloproteinase Inhibitors in Cancer Therapy. Humana Press, 2001, vol 2, pp. 39-66.

87 Comar M, Zanotta N, Zanconati F, Cortale M, Bonotti A, Cristaudo A, Bovenzi M: Chemokines involved in the early inflammatory response and in pro-tumoral activity in asbestos-exposed workers from an Italian coastal area with territorial clusters of pleural malignant mesothelioma. Lung Cancer 2016;94:61-67.

88 Amati M, Tomasetti M, Mariotti L, Tarquini LM, Valentino M, Santarelli L: Assessment of biomarkers in asbestos-exposed workers as indicators of cancer risk. Mutat Res Genet Toxicol Environ Mutagen 2008;695:52-58.

89 Ledda C, Senia P, Rapisarda V: Biomarkers for early diagnosis and prognosis of malignant pleural mesothelioma: The quest goes on. Cancers (Basel) 2018;10:203. 